\title{
Continental crust in the Davis Strait: new evidence from seabed sampling
}

\author{
Finn Dalhoff, Lotte M. Larsen, Jon R. Ineson, Svend Stouge, Jørgen A. Bojesen-Koefoed, \\ Susanne Lassen, Antoon Kuijpers, Jan A. Rasmussen and Henrik Nøhr-Hansen
}

Although the structural framework of the subsurface offshore West Greenland has been well documented based on comprehensive seismic analysis (cf. Dalhoff et al. 2003), the stratigraphy of the region is less well known. The oldest documented sedimentary rocks drilled offshore West Greenland are Santonian sandstones reached at TD in the 6354/4-1 well (Fig. 1) although reworked palynomorphs of Carboniferous, Triassic and Jurassic (Kimmeridgian) age have been reported from a number of wells in the region. In order to obtain better constraints on the pre-Upper Cretaceous stratigraphy, a preliminary screening was undertaken to identify inversion structures and erosional canyons where such deeper stratigraphic levels crop out at the seabed (Nielsen et al. 2001). Sea-floor sampling at selected sites between $62^{\circ}$ and $67^{\circ} \mathrm{N}$ (Fig. 1) was undertaken during the summers of 2003 and 2004. Other objectives of these cruises were to seek direct evidence of active petroleum systems, to establish further constraints on tectonic and stratigraphic models, and to obtain a better understanding of the Neogene and Pleistocene history of the region (Dalhoff et al. 2005).

The most promising seabed features identified by Nielsen et al. (2001) were investigated in more detail using a wide range of techniques in order to optimise sampling positions. In 2003, these techniques included echo sounder, side-scan sonar, singlechannel seismic and video inspection before sampling either by dredge, gravity corer, or by video-controlled grab. In 2004, comprehensive data acquisition with a deep-water sparker system was undertaken before sampling by dredge or gravity corer, supplemented by grab samples at selected stations.

\section{Sampling}

A total of 19 dredges and five gravity cores, together with three grab samples, were recovered from the eastern and western flank of canyon $\mathrm{C}_{1}$ (Fig. 1). On the Davis Strait High, four dredge and four grab stations were located on the eastern flank and one gravity core was recovered from the western flank (Fig. 1). Sampling at the seamounts was carried out by dredge on the flanks (six stations) with one grab station at the top of seamount $S_{3}$ (Fig. 1). Twenty-six gravity core stations and one piston core station were located in the areas with shallow Direct Hydrocarbon Indications (DHI), inferred from seismic anomalies or from sea-surface slicks recognised on satellite data; the majority were taken within $\mathrm{D}_{1}$ and $\mathrm{D}_{2}$ with the remaining five stations covering D3 and $\mathrm{D}_{4}$ (Fig. 1). However, none of the samples produced significant hydrocarbon readings.

From a survey on the Labrador Shelf, McMillan (1973) reported a positive correlation between sea-floor outcrop and debris composition and concluded that only a small proportion of the recovered rock samples are ice rafted debris (IRD). In this study, differentiation between in situ samples and IRD

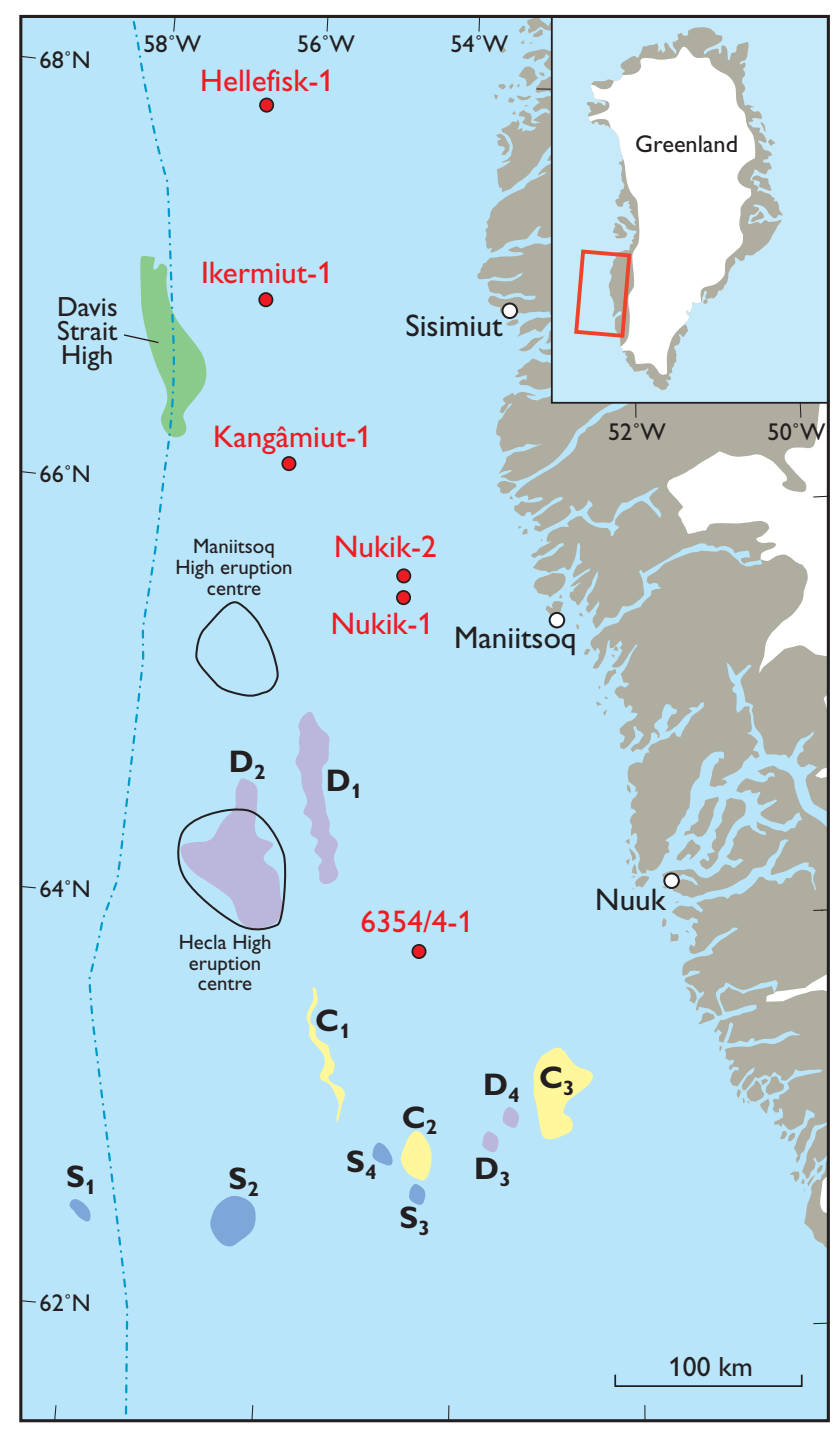

Fig. 1. Map of Labrador Sea and Davis Strait showing sample objectives of the 2003 and 2004 seabed sampling programme referred to in the text. 
is based on the number of samples and the lithological homogeneity of the rock types collected at each station. For each dredge and grab station, the samples were classified into three groups: sedimentary rocks (siliciclastic and carbonates), igneous rocks, and Precambrian crystalline rocks.

\section{Quaternary sedimentation}

Understanding of Quaternary sedimentation patterns offshore West Greenland has greatly improved based on these surveys. Gravity cores from the site survey acquired prior to drilling the 6354/4-1 well (Fig. 1) and the 37 cores from the seabed sampling programme between $62^{\circ} \mathrm{N}-67^{\circ} \mathrm{N}$ have formed the basis for a detailed stratigraphic study of the uppermost sediment package (Lassen et al. 2005). Based on magnetic susceptibility profiles, ${ }^{14} \mathrm{C}$ accelerator-mass-spectrometry $\left(\mathrm{AMS}^{14} \mathrm{C}\right)$ dates and core descriptions, it has been possible to relate the succession in the study areas to published event stratigraphic schemes. In general, cores from intermediate water depths (all areas except $\mathrm{D}_{2}$ and the Davis Strait High, see Fig. 1) contain hemipelagic sediments alternating with IRD-rich layers. Since this pattern is found in all of the studied areas, it is concluded that no resedimentation of the upper sediments has occurred.

\section{Ordovician and Jurassic sediments}

The identification of dipping reflectors extending up to or near the seabed on conventional seismic lines presented the possibility of sampling sedimentary successions of unknown age at several stations. Test sampling (one gravity core) on the eastern flank of canyon $\mathrm{C}_{1}$ (Fig. 1) in 2002 revealed reworked Middle-Upper Jurassic and Lower Cretaceous palynomorphs (H. Nøhr-Hansen, unpublished data 2004). Extensive sampling at this locality was undertaken and a pseudo stratigraphy has been established with the Danian-Selandian boundary identified on the western flank and the presence of Archaean crystalline basement overlain by Upper Ordovician - Lower Silurian carbonates and marine Mesozoic sediments on the eastern flank.

At the Davis Strait High sampling was undertaken together with a wide range of geophysical investigations indicating the presence of a possible inverted Palaeozoic carbonate platform. The assemblage of sedimentary rock types dredged up from the eastern side of the high (Fig. 1) is characterised in particular by marine carbonates, which form over $60 \%$ of the dredge clasts. Other rock types include fragments of sandstone, Precambrian crystalline rocks and igneous rocks. The carbonates comprise a range of lithofacies from biomottled lime mudstones and skeletal wackestones (about half of the carbonate clasts from both Davis Strait High sites) through skeletal, peloidal and intraclastic packstones and grainstones to rare microbial carbonates, including oncolitic and stromatolitic carbonates. Partially and wholly dolomitised representatives of these lithofacies are also present. Quartz silt and sand are common within the carbonates and fine-grained calcareous or dolomitic sandstones in the sample set are thought to form part of the facies spectrum. The bioclasts within these carbonates include crinoid, brachiopod, mollusc, bryozoan, coral, stromatoporoid, ostracod and trilobite fragments, testifying to the open marine, Palaeozoic affinity of the sediments; the facies represented record primarily a low-energy subtidal setting, although high-energy subtidal and lagoonal/intertidal settings are also indicated.

Organic geochemical analyses of the sedimentary rocks have only revealed two samples with promising results. One sample from canyon $\mathrm{C}_{1}$ and one sample from the Davis Strait High (Fig. 1). The sample from canyon $C_{1}$ is a laminated Upper Ordovician mudstone, showing Hydrogen Index $\sim 400$, Total Organic Carbon $=1.3-4 \%$ and generative potential $\left(\mathrm{S}_{2}\right.$-value) that indicates a type 2 source rock with good to excellent potential for oil generation. For a marine carbonate, the biomarker signature shows unusually high proportions of gammacerane, 28-nor-spergulanes (Nytoft et al. 2006) and tetracyclic polyprenoids (TPP) and very high proportions of $\mathrm{C}_{29}$ regular steranes. Similar characteristics are found in samples of the Aleqatsiaq Fjord Formation in North Greenland (Christiansen 1989) and in Ordovician carbonates from Hudson Bay and around Foxe Basin, Canada (M.G. Fowler, personal communication 2004). The sample from the Davis Strait High is an Ordovician carbonate with oil staining of same age as seen in the source rock from canyon $C_{1}$.

Biostratigraphic studies indicate a Late Ordovician age (Maysvillian to Richmondian) for Davis Strait High sample suite, suggesting correlation with Lower Palaeozoic carbonate successions of the south-east Arctic Platform and the Hudson Platform in eastern and north-eastern Canada (Sanford \& Grant 2000) and North Greenland, and 'Fossilik' in West Greenland (Stouge \& Peel 1979). The correlation with Canada and North Greenland is supported by the geochemical data.

\section{Igneous rocks}

Igneous rocks constitute $10-20 \%$ of the clast population in most of the dredges, which is a much larger proportion than in the onshore areas. The clasts are typically $5-25 \mathrm{~cm}$ in size, rarely $>30 \mathrm{~cm}$ across. The majority are massive or vesiculated, fine-grained plagioclase-phyric or aphyric basalts. There are a few oxidised and brecciated samples interpreted as flow tops, and some picrites and gabbros. The clasts vary from angular to rounded and nearly all show abrasion indicative of transportation. Notable exceptions are two irregular, 
very friable rock fragments from seamount $S_{2}$ (Fig. 1) which must be very local.

Of the total of 195 igneous rock samples, 95 were selected for geochemical analysis. Of these, 12 are interpreted to be of Precambrian age based on petrography (alteration) and geochemistry, and they are considered to be IRD; these include the gabbro samples. The remaining 83 samples can be grouped into relatively few geochemical groups (Fig. 2).

All the analysed samples from the Davis Strait High are tholeiitic basalts showing moderate to strong depletion in the most incompatible elements, with REE patterns sloping down to the left (Fig. 2A) and low $\mathrm{Nb} / \mathrm{La}$ and $\mathrm{Nb} / \mathrm{Lu}$ ratios mostly $<1$ (Fig. 2B). Four samples have increased contents of a number of elements notably $\mathrm{Si}, \mathrm{K}, \mathrm{Rb}, \mathrm{Ba}$, Th and $\mathrm{Pb}$, and are depleted in $\mathrm{Nb}$ indicating contamination by continental crustal material (Fig. 2B).

In the region south of $64^{\circ} \mathrm{N}$ the majority of samples belong to one geochemical type (the 'main group'). These rocks are tholeiitic basalts with moderate contents of incompatible elements, REE patterns sloping down to the right (Fig. 2A), and $\mathrm{Nb} / \mathrm{La}$ and $\mathrm{Nb} / \mathrm{Lu}$ ratios $>1$ (Fig. 2B). A group of eight samples have relatively flat REE patterns and $\mathrm{Nb} / \mathrm{La}$ and $\mathrm{Nb} / \mathrm{Lu}$ ratios close to one. Two of these samples show signs of crustal contamination (Fig. 2B). A group of six samples are enriched tholeiitic basalts with steeper REE patterns and higher $\mathrm{Nb}$ contents than the main group. Two friable samples of obvious local origin from seamount $S_{2}$ are alkaline; they are basanites with steep REE patterns and high $\mathrm{Nb} / \mathrm{Lu}$ ratios $>10$ (Fig. 2). Other samples include two probably crustally contaminated basaltic andesites and two different rhyolites.

Radiometric ages have been obtained by the ${ }^{40} \mathrm{Ar} /{ }^{39} \mathrm{Ar}$ step-heating technique for 12 samples. One sample from the flat-patterned group yielded $119 \pm 1 \mathrm{Ma}$ (Early Cretaceous), one sample from the Davis Strait High yielded 63.0 $\pm 0.7 \mathrm{Ma}$ (Early Paleocene), whereas ten samples from the region south of $64^{\circ} \mathrm{N}$ yielded ages ranging from $58.0 \pm 0.4 \mathrm{Ma}$ to $48.1 \pm$ 0.9 Ma (Late Paleocene - Early Eocene).

Several lines of evidence support a relatively local derivation for the Palaeogene igneous rocks. The high abundance of igneous clasts in the dredges is incompatible with the absence of such rocks in the neighbouring onshore areas. If the basalts in the dredges in the southern region were ice-rafted from the northern onshore volcanic areas in West Greenland and Baffin Island, they should have the same composition and be more frequent in the northern dredges, but this was not observed.

The geochemically depleted rocks from the Davis Strait High are compositionally similar to lava flows outcropping on the sea floor in the same area and sampled in short drill cores (Srivastava et al. 1982; M.-C. Williamson, unpublished data), making a strong argument for local derivation of these
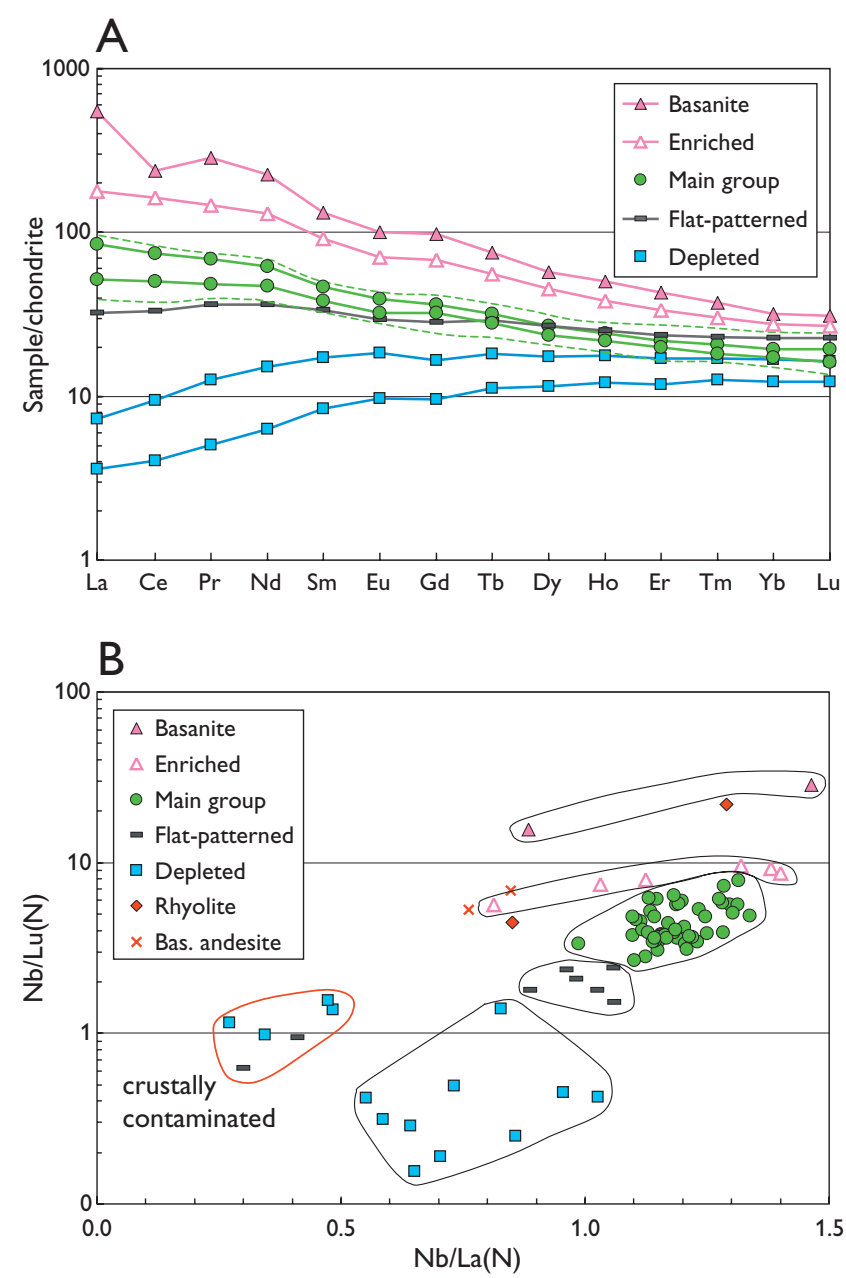

Fig. 2. Geochemistry of the dredged igneous rocks. A: Rare earth element (REE) patterns for representative samples, chondrite normalised data. The dotted green lines indicate the compositional range of the 'main group'. B: $\mathrm{Nb} / \mathrm{Lu}$ vs $\mathrm{Nb} / \mathrm{La}, \mathrm{N}$ means primitive mantle normalised data. Normalisation values for both plots from McDonough \& Sun (1995).

samples. The crustally contaminated samples support the presence of continental crust in the Davis Strait High, as suggested by Keen et al. (1974).

The stations south of $64^{\circ} \mathrm{N}$ are situated immediately south of the large volcanic complexes of the Hecla High Eruption Centre (Fig. 1). The lava succession of the Hecla High is dated as Eocene, and seismic sections show that an eroded and tilted cuesta landscape of lava flows has been exposed subaerially until some time during the Pleistocene (Sørensen 2005). It is therefore considered most likely that the dredged volcanic rocks from south of $64^{\circ} \mathrm{N}$ are derived from the Hecla High.

Seamount $S_{2}$ (Fig. 1) is flat-topped with a number of small volcanic cones rising from the platform. The cones probably consist of strongly alkaline rocks as judged from the occurrence of very local samples of basanite. 
The slopes of the REE patterns indicate that the geochemically depleted basalts from the Davis Strait High were produced by melting to relatively shallow levels in the spinel stability field in the mantle, i.e. beneath a relatively thin $(<80$ $\mathrm{km})$ lithospheric lid. However, the contaminated samples show that they also came into contact with continental crust. The non-depleted and enriched basalts from the Hecla High were produced by melting at deeper levels in the garnet stability field in the mantle beneath a thicker lithospheric lid, and the basanites from seamount $S_{2}$ were produced by the smallest degrees of melting at the deepest levels. The mantle source could in all cases be the proto-Icelandic mantle plume. For a more detailed discussion of the igneous rocks see Larsen \& Dalhoff (2006).

\section{Archaean gneiss}

Two dredges on the eastern side of canyon $C_{1}$ yielded Precambrian gneisses that are considered to be of local origin because of the uniform lithology and unabraded angular morphologies. Dating of a gneiss sample by the ${ }^{206} \mathrm{~Pb} /{ }^{207} \mathrm{~Pb}$ method yielded a well-defined Archaean age $(2740 \pm 150 \mathrm{Ma})$ with no indications of later thermal events. This is compatible with ages derived from the gneisses of the central Archaean craton of West Greenland, suggesting that the basement gneisses exposed in canyon $\mathrm{C}_{1}$ represent the offshore continuation of this cratonic basement complex. This would extend the known occurrence of Archaean basement to nearly $200 \mathrm{~km}$ offshore, well into areas that were previously interpreted to comprise oceanic crust (Srivastava 1978; Roest \& Srivastava 1989).

\section{Conclusion and future work}

The seabed sampling programme has yielded much new information on the Early Palaeozoic, Mesozoic and Palaeogene history of the Davis Strait and Labrador Sea including the extension of the continental crust into areas earlier described as oceanic crust. Continuation of the project with extension of the sampling region to $71^{\circ} \mathrm{N}$, west of Disko, is planned for the summer of 2006 with collection of additional geophysical data and samples in selected areas.

\section{Acknowledgement}

The Bureau of Minerals and Petroleum, Nunaoil A/S and EnCana Corporation are thanked for financial support.

\section{References}

Christiansen, F.G. 1989: Petroleum geology of North Greenland. Bulletin Grønlands Geologiske Undersøgelse 158, 92 pp.

Dalhoff, F., Chalmers, J.A., Gregersen, U., Nøhr-Hansen, H., Rasmussen, J.A. \& Sheldon, E. 2003: Mapping and facies analysis of Paleocene Mid-Eocene seismic sequences, offshore southern West Greenland. Marine and Petroleum Geology 20, 935-986.

Dalhoff, F., Kuijpers, A., Nielsen, T., Lassen, S., Bojesen-Koefoed, J.A., Larsen, L.M., Stouge, S., Rasmussen, J.A. \& Nøhr-Hansen, H. 2005: Seabed sampling offshore West Greenland - new information of inverted Palaeozoic and Mesozoic basins. GAC-MAC-CSPG-CSSS Joint Meeting , Halifax, Nova Scotia, Canada, 15-18 May, 2005, Abstracts 30, 39 only.

Keen, C.E., Keen, M.J., Ross, D.I. \& Lack, M. 1974: Baffin Bay: small ocean basin formed by seafloor spreading. American Association of Petroleum Geologists Bulletin 58, 1098-1108.

Larsen, L.M. \& Dalhoff, F. 2006: Composition, age, and geological and geotectonic significance of igneous rocks dredge from the Labrador Sea and the Davis Strait. Danmarks og Grønlands Geologiske Undersøgelse Rapport 2006/43, 73 pp.

Lassen, S.J., Dalhoff, F., Kuijpers, A. \& Nielsen, T. 2005: Late Quaternary sedimentation patters offshore West Greenland based on magnetic susceptibility profiles. Danmarks og Grønlands Geologiske Undersøgelse Rapport 2005/71, 12 pp.

McDonough, W.F. \& Sun, S.-S. 1995: The composition of the Earth. In: McDonough, W.F. et al. (eds): Chemical evolution of the mantle. Chemical Geology 120, 223-253.

McMillan, N.J. 1973: Surficial geology of Labrador and Baffin Island shelves. In: Hood, P.J. (ed.): Earth science symposium on offshore eastern Canada. Geological Survey of Canada, Paper 71-23, 451-469.

Nielsen, T., Andersen, C., Jensen, J.B., Kuijpers, A., Marcussen, C., Piasecki, S., Sønderholm, M. \& Rasmussen, R. 2001: Geohazard 2001 study offshore West Greenland. Danmarks og Grønlands Geologiske Undersøgelse Rapport 2001/127, 64 pp.

Nytoft, H.P., Lutnæes, B.F. \& Johansen, J.E. 2006: 28-Nor-spergulanes, a novel series of rearranged hopanes. Organic Geochemistry 37, 772-786.

Roest, W.R. \& Srivastava, S.P. 1989: Sea-floor spreading in the Labrador Sea; a new reconstruction. Geology 17, 1000-1003.

Sanford, B.V. \& Grant, A.C. 2000: Geological framework of the Ordovician system in the Southeast Arctic Platform, Nunavut. In: McCracken, A.D. \& Bolton, T.E. (eds): Geology and paleontology of the Southeast Arctic Platform and southern Baffin Island, Nunavut. Geological Survey of Canada Bulletin 557, 13-38.

Sørensen, A.B. 2006: Stratigraphy, structure and petroleum potential of the Lady Franklin and Maniitsoq Basins, offshore southern West Greenland. Petroleum Geoscience 12, 221-234.

Srivastava, S.P. 1978: Evolution of the Labrador Sea and its bearing on the early evolution of the North Atlantic. Geophysical Journal of the Royal Astronomical Society 52, 313-357.

Srivastava, S.P., Maclean, B., Macnab, R.F. \& Jackson, H.R. 1982: Davis Strait: Structure and evolution as obtained from a systematic geophysical survey. In: Embry, A.F. \& Balkwill, H.R. (eds): Arctic geology and geophysics. Canadian Society of Petroleum Geologists Memoir 8, 267-278.

Stouge, S. \& Peel, J.S. 1979: Ordovician conodonts from the Precambrian Shield of southern West Greenland. Rapport Grønlands Geologiske Undersøgelse 91, 105-109.

\section{Authors' addresses}

F.D., L.M.L., J.R.I., S.S., J.B.-K., A.K. \& H.N.-H., Geological Survey of Denmark and Greenland, Øster Voldgade 10, DK-1350 Copenhagen K, Denmark. E-mail: fd@geus.dk

S.L., 96 Settrington Road, London SW6 3BA, UK.

J.A.R., Geological Museum, University of Copenhagen, Øster Voldgade 5-7, DK-1350 Copenhagen K, Denmark. 